\title{
PraWne ASPeKTy uZALeŻNiENia DZIECI
}

\section{Wstęp}

Regulacją określającą prawa dzieci do opieki zdrowotnej jest ustawa z dnia 27 sierpnia 2004 r. o świadczeniach opieki zdrowotnej finansowanych ze środków publicznych ${ }^{1}$. W tej ustawie prawa dzieci do opieki zdrowotnej zostały nie tylko scharakteryzowane w ramach praw przysługujących wszystkim osobom uprawnionym do świadczeń, ale także jako prawa stosowane wyłącznie w stosunku do dzieci².

Dzieci, które nie spełniają wymogów ustawowych do tego, żeby w rozumieniu u.ś.o.z. były uznane jako „ubezpieczone”, posiadają uprawnienie do pozyskania świadczeń opieki zdrowotnej zagwarantowanych w tej ustawie na podstawie normy wynikającej z art. 2 ust. 1 pkt 3 u.ś.o.z. ${ }^{3}$

Dzieci będące świadczeniobiorcami (bez względu na to, czy są ubezpieczone) mają z tego tytułu na ogólnych zasadach określonych w art. 15 ust. 1 u.ś.o.z. dostęp do świadczeń opieki zdrowotnej udzielanych wszystkim świadczeniobiorcom w celu: zachowania zdrowia, zapobiegania chorobom i urazom, wczesnego wykrywania chorób, leczenia, pielęgnacji oraz zapobiegania niepełnosprawności i jej ograniczania. Na tej samej zasadzie,

* Dr, Wyższa Szkoła Logistyki w Poznaniu, adwokat; e-mail: k.golusinka@dgip.pl.

* Mgr, Wyższa Szkoła Logistyki w Poznaniu, adwokat; e-mail: kruczek@kg-adwokaci.pl.

1 Ustawa z dnia 27 sierpnia 2004 r. o świadczeniach opieki zdrowotnej finansowanych ze środków publicznych, tekst jednolity: Dz. U. z 2019 r. poz. 1373 z późn. zm. (dalej: u.ś.o.z.).

2 Zob. M. Dercz, Konstytucyjne prawo dziecka do szczególnej opieki zdrowotnej, Warszawa 2016, s. 13-14.

3 Tamże. 
na podstawie art. 15 ust. 2 u.ś.o.z., dzieci mają gwarantowane ustawowo świadczenia zawierające: podstawową opiekę zdrowotną, ambulatoryjną opiekę specjalistyczną, leczenie szpitalne, opiekę psychiatryczną i leczenie uzależnień, rehabilitację leczniczą, świadczenia pielęgnacyjne i opiekuńcze $\mathrm{w}$ ramach opieki długoterminowej, leczenie stomatologiczne, lecznictwo uzdrowiskowe, zaopatrzenie $\mathrm{w}$ wyroby medyczne, ratownictwo medyczne, opiekę paliatywną i hospicyjną, świadczenia wysokospecjalistyczne, programy zdrowotne, leki, środki spożywcze specjalnego przeznaczenia żywieniowego oraz wyroby medyczne dostępne w aptece na receptę, a także programy lekowe i stosowane $\mathrm{w}$ chemioterapii określone $\mathrm{w}$ przepisach ustawy o refundacji ${ }^{4}$. Należy także pamiętać, że dzieci mają prawo do świadczeń opieki zdrowotnej udzielanych bezpłatnie, w oparciu o odpowiednie dyspozycje ustaw wymienionych $\mathrm{w}$ katalogu zawartym $\mathrm{w}$ art. 12 u.ś.o.z. ${ }^{5}$

\section{Uzależnienie dzieci od alkoholu}

Zgodnie z wnioskami ankiety ESPAD przeprowadzonej w 2015 r. na temat używania substancji psychoaktywnych przez młodzież, zalicza się ona, niestety w większości, do konsumentów alkoholu - pije przede wszystkim piwo, rzadziej sięga po inne napoje. Poważnym problemem jest natomiast upijanie się. . Prawo reaguje na te niepokojące tendencje za pomocą narzędzi o charakterze administracyjnym i karnym.

Tradycyjnie $w$ nauce prawa administracyjnego przedmiotem regulacji ustawy uważa się wskazaną $\mathrm{w}$ ustawie przez ustawodawcę sferę stosunków społecznych, poddaną regulacji, a więc pewnej kwalifikacji prawnej za pośrednictwem norm prawnych powszechnie obowiązujących, określających atrybuty (cechy) swoich adresatów. Oznacza to, że do tej pory obojętna

4 Przepisy u.ś.o.z. wypełniają normę przybierającą postać zasady prawa, zawartą w art. 68 ust. 3 Konstytucji RP, stanowiącą, że władze publiczne są obowiązane do zapewnienia szczególnej opieki zdrowotnej dzieciom, kobietom ciężarnym, osobom niepełnosprawnym i osobom w podeszłym wieku.

5 Tamże.

6 Zob. J. Sierosławski, Używanie substancji psychoaktywnych przez młodzież w 2015 r., Europejski Program Badań Ankietowych w Szkołach na temat używania alkoholu i narkotyków, prezentacja (analiza wyników) Espad, http://www.cinn.gov.pl/portal?id=907006 [dostęp: 22.05.2018 r.]. 
(irrelewantna) z prawnego, tj. normatywnego punktu widzenia sfera stosunków społecznych została objęta normatywnymi wzorami powinnego zachowania się adresatów normy, których realizacja będzie weryfikowana przez organy władzy publicznej ${ }^{7}$.

Ustawodawca pozostawił gminom regulacje prawne w tym zakresie. Treść ustawy nakłada określone na gminę obowiązki, a mianowicie wskazuje się na przykład ogólnie obowiązujące zasady usytuowania miejsc sprzedaży napojów alkoholowych na terenie gminy, stanowiąc, że punkty sprzedaży napojów alkoholowych (detal) nie mogą być zlokalizowane w odległości mniejszej niż 100 metrów od następujących obiektów: szko$\mathrm{ły}^{8}$ podstawowe i średnie; przedszkola; obiekty sportowe; domy dziecka; dworce kolejowe i autobusowe; stanowiska portowo-rzeczne; zakłady dla nieletnich; ośrodki karno-wychowawcze; obiekty kultu religijnego; kąpieliska, zalewy, baseny; ogródki jordanowskie oraz ogólnodostępne, zorganizowane i ogrodzone place zabaw dla dzieci; inne placówki oświatowo-wychowawcze, funkcjonujące co najmniej rok, w których odbywają się zajęcia pozalekcyjne dla dzieci i młodzieży do lat 18.

Ponadto z treści orzeczenia Naczelnego Sądu Administracyjnego wynika, że przy realizacji zadań, o których mowa w art. 1 ust. 1 i art. 2 ust. 1 ustawy z dnia 26 października 1982 r. o wychowaniu w trzeźwości i przeciwdziałaniu alkoholizmowi ${ }^{9}$, administracja publiczna musi uwzględniać zobowiązania prawnomiędzynarodowe.

Zadania organów administracji państwowej w zakresie przeciwdziałania alkoholizmowi (art. 1 ust. 1 i art. 2 ust. 2 [u.ozw.alk.] powinny być realizowane również z uwzględnieniem zobowiązań prawno-międzynarodowych wynikających z art. 3 Konwencji o Prawach Dziecka (Dz. U. 1991 nr 120 poz. 526) tak, aby interesy dzieci doznały najlepszego zabezpieczenia, a rodzina jako

7 I. Skrzydło-Niżnik, G. Zalas, Ustawa o wychowaniu w trzeźwości i przeciwdziałaniu alkoholizmowi. Komentarz, Kraków 2002, LEX 2018.

8 „Przyjęta przez Radę Gminy odległość 15 m miejsc sprzedaży i podawania napojów alkoholowych od obiektów chronionych oznacza bardzo bliskie, bezpośrednie sąsiedztwo z takimi obiektami, co w oczywisty sposób kłóci się z koniecznością realizowania obowiązku ograniczania dostępności do alkoholu, w szczególności w stosunku do osób nieletnich", wyrok Wojewódzkiego Sądu Administracyjnego w Lublinie z dnia 24 września 2013 r., III SA/Lu 335/13, Centralna Baza Orzeczeń Sądów Administracyjnych (CBOSA).

9 Ustawa z dnia 26 października 1982 r. o wychowaniu w trzeźwości i przeciwdziałaniu alkoholizmowi, tekst jednolity: Dz. U. z 2018 r. poz. 2137 (dalej: u.ozw.alk.). 
podstawowa komórka społeczna oraz naturalne środowisko rozwoju i dobra wszystkich jej członków, a w szczególności dzieci, otoczona została niezbędną ochroną oraz wsparciem i mogła w pełnym zakresie wypełniać swoje obowiązki w społeczeństwie (preambuła Konwencji) ${ }^{10}$.

\section{Izba wytrzeźwień}

Treść art. 40 u.ozw.alk. stanowi, iż osoby w stanie nietrzeźwości, które swoim zachowaniem dają powód do zgorszenia w miejscu publicznym lub w zakładzie pracy, znajdują się w okolicznościach zagrażających ich życiu lub zdrowiu albo zagrażają życiu lub zdrowiu innych osób, mogą zostać doprowadzone do izby wytrzeźwień, zakładu opieki zdrowotnej lub innej właściwej placówki utworzonej lub wskazanej przez jednostkę samorządu terytorialnego albo do miejsca zamieszkania lub pobytu.

W odniesieniu do będących w stanie nietrzeźwym osób małoletnich poniżej 18 roku życia, których zachowanie uzasadniało doprowadzenie ich do izby wytrzeźwień lub na komisariat (posterunek) policji, ustawodawca nakazał umieszczanie ich w odrębnych pomieszczeniach, oddzielnie od osób dorosłych, a nadto w przypadku umieszczenia osoby małoletniej w izbie wytrzeźwień nakazał zawiadomienie jej rodziców lub opiekunów oraz sądu opiekuńczego ${ }^{11}$. Rozporządzenie Ministra Zdrowia ${ }^{12}$ precyzuje, iż osoby małoletnie przekazuje się po wytrzeźwieniu rodzicom lub innym prawnym opiekunom, a w razie ich braku lub niezgłoszenia się - pogotowiu opiekuńczemu lub policyjnej izbie dziecka. Zwrócić należy szczególną uwagę na fakt, iż osoba małoletnia zwalniana z izby wytrzeźwień musi z niej zostać odebrana przez osobę do tego uprawnioną, tj. rodziców lub ustanowionego przez sąd opiekuna prawnego, w żadnym wypadku osoba małoletnia nie może izby wytrzeźwień opuścić sama ani też w towarzystwie osób przypadkowych - innych niż określone w cytowanych przepisach ${ }^{13}$.

10 Wyrok Naczelnego Sądu Administracyjnego oz. w Katowicach z dnia 13 lipca 1994 r., SA/KA 30/94, CBOSA.

11 Tamże; treść za: I. Skrzydło-Niżnik, G. Zalas, Ustawa o wychowaniu..., LEX 2018.

12 Rozporządzenie Ministra Zdrowia z dnia 8 grudnia 2014 r. w sprawie izb wytrzeźwień i placówek wskazanych lub utworzonych przez jednostkę samorządu terytorialnego, Dz. U. z 2014 r. poz. 1850.

13 Zob. I. Skrzydło-Niżnik, G. Zalas, Ustawa o wychowaniu..., LEX 2018. 


\section{Uzależnienie dzieci od narkotyków}

Przedstawiciele praktyki związani ze zwalczaniem narkomanii dążyli przez lata do wprowadzenia odpowiednich rozwiązań prawnych. Uwidoczniła się wobec tego przede wszystkim potrzeba określenia prawnej definicji narkomanii i szeregu pojęć związanych z samym zjawiskiem odurzania, które jednocześnie pozwoliłyby zakończyć istniejące spory terminologiczne ${ }^{14}$.

Pojęcie "narkomanii” w rozumieniu aktualnie obowiązującej ustawy z dnia 29 lipca 2005 r. o przeciwdziałaniu narkomanii ${ }^{15}$ jest bardzo szerokie. Zgodnie z treścią art. 4 pkt 11 u.p.n. narkomania to stałe lub okresowe zażywanie $\mathrm{w}$ celach niemedycznych środków odurzających, substancji psychotropowych, środków zastępczych lub nowych substancji psychoaktywnych, w wyniku czego może powstać lub powstało uzależnienie od nich. Nie każde zatem przyjmowanie w celach niemedycznych środków odurzających lub psychotropowych albo środków zastępczych jest narkomanią. W rozumieniu powołanego przepisu narkomania występuje wtedy, gdy środki są przyjmowane stale lub okresowo (a nie np. okazjonalnie lub doświadczalnie), co może prowadzić do uzależnienia ${ }^{16}$. Uzależnienie od środków odurzających lub substancji psychotropowych to zespół zjawisk psychicznych lub somatycznych wynikających z działania tych środków lub substancji na organizm ludzki, charakteryzujący się zmianą zachowania lub innymi reakcjami psychofizycznymi i koniecznością używania stale lub okresowo tych środków lub substancji w celu doznania ich wpływu na psychikę lub dla uniknięcia następstw ${ }^{17}$ wywołanych ich brakiem (art. 4 pkt 29 u.p.n.). Jak wynika z powyższego, pojęciem „uzależnienie" w znaczeniu przyjętym w ustawie z 1997 r. objęto uzależnienie

14 Zob. A. Muszyńska, Narkomani. Sprazwcy czynów karalnych, Kraków 2004, s. 27.

15 Ustawa z dnia 29 lipca 2005 r. o przeciwdziałaniu narkomanii, tekst jednolity: Dz. U. z 2019 r. poz. 852 (dalej: u.p.n.).

16 „Jednorazowe użycie środka odurzającego lub substancji psychotropowej nie powoduje jeszcze uzależnienia, jednakże wzrasta prawdopodobieństwo jego powstania, w szczególności w przypadku tzw. narkotyków twardych. Eksperymentalne użycie prowadzi niejednokrotnie do używania okolicznościowego, które w wielu przypadkach kończy się uzależnieniem, w szczególności, jeśli chodzi o narkotyki twarde", T. Srogosz, Ustawa o przeciwdziałaniu narkomanii. Komentarz, Warszawa 2008, s. 111.

17 Następstwem będzie każde ograniczenie zdolności kierowania swoim postępowaniem. 
fizyczne i psychiczne (bez uzależnienia społecznego ${ }^{18}$ ). Wprowadzając definicję „narkomanii” do systemu prawa, ustawodawca pominął objaśnienie pojęcia „narkoman”. W miejsce tego posłużył się pojęciem „osoby uzależnionej” i „osoby zagrożonej uzależnieniem”. Definicja legalna „narkomanii" pozwala jednakże dokonać - drogą wnioskowania - ustalenia, że „narkoman” to osoba używająca stale bądź okresowo środków odurzających, substancji psychotropowych, środków zastępczych lub nowych substancji psychoaktywnych ${ }^{19} \mathrm{w}$ celach niemedycznych, w wyniku czego może powstać lub powstało uzależnienie od nich.

"Uzależniony" z kolei to osoba znajdująca się w stanie uzależnienia od środków odurzających, substancji psychotropowych lub środków zastępczych w wyniku nadużywania tych środków albo używania ich w celach medycznych.

Pojęcie „osoby zagrożonej uzależnieniem” jest szersze od pojęcia „osoby zagrożonej narkomanią”, które to pojęcie mogłoby zostać wywiedzione z definicji narkomanii, a oznaczałoby osobę stale bądź okresowo używającą środków odurzających, substancji psychotropowych, środków zastępczych lub nowych substancji psychoaktywnych w celach niemedycznych, w wyniku czego mogłoby powstać uzależnienie.

"Osobą uzależnioną" jest również osoba używająca wyżej wskazanych środków w celach medycznych i znajdująca się w stanie uzależnienia. Metoda językowej wykładni prawa nie pozwalałaby nazwać takiej osoby „narkomanem”, a to ze względu na okoliczność, że przyjmowała ona wprawdzie środki odurzające, lecz następowało to w procesie leczenia i zgodnie z przyjętą praktyką lekarską ${ }^{20}$.

18 Zachodzi wówczas, gdy używanie określonego środka jest wynikiem interakcji zachodzących pomiędzy jednostką a grupą, a konkretniej konsekwencją działania mechanizmów skłaniania do konformizmu z normami grupy odniesienia dla jednostki, zob. A. Gaberle, Patologia społeczna, Warszawa 1993, s. 53-59.

19 Wprowadzenie pojęcia "nowej substancji psychoaktywnej” do ustawy miało na celu wyodrębnienie, przez stanowiony nowelizacją z dnia 24 kwietnia 2015 r. Zespół do spraw oceny ryzyka zagrożeń dla zdrowia lub życia ludzi związanych z używaniem nowych substancji psychoaktywnych, substancji, które wykazują działanie na ośrodkowy układ nerwowy pod względem stwarzania bezpośredniego zagrożenia dla zdrowia lub życia ludzi, jak również powodowania szkód społecznych. Tym samym pozwoliło to na stworzenie listy substancji, których wytwarzanie i wprowadzanie do obrotu jest zabronione na gruncie prawa administracyjnego.

20 „Lekomania (farmakomania) jest to nadużywanie leku lub leków polegające na stosowaniu danej substancji chemicznej (lub kilku) przez dłuższy czas dla korzyści płynących 
Oddanie istoty pojęcia „osoby uzależnionej” polega zatem na objęciu zakresem normowania zarówno osób nadużywających wymienionych wyżej środków w celach niemedycznych jak i medycznych.

Dalsze rozważania muszą być poprzedzone rozróżnieniem pojęć: "nieletni narkoman” na gruncie ustawy o postępowaniu w sprawach nieletnich ${ }^{21}$ oraz „małoletni narkoman” w rozumieniu Kodeksu cywilnego ${ }^{22}$.

Pierwsze z wyżej wskazanych pojęć, wynikające z art. 1 § 2 pkt 1 powołanego aktu prawnego obejmuje następujące kategorie osób:

a) w zakresie zapobiegania i zwalczania demoralizacji - osoby, które nie ukończyły 18 lat,

b) w postępowaniu o czyny karalne - osoby, które w chwili popełnienia takiego czynu ukończyły lat 13, lecz nie ukończyły lat 17,

c) w zakresie wykonywania środków wychowawczych lub poprawczych - osoby, które nie ukończyły lat 21.

Ustawa o postępowaniu w sprawach nieletnich nie posługuje się pojęciami „osoba uzależniona” ani „osoba zagrożona uzależnieniem”. W art. 4 $\S 1$ mowa z kolei o "okolicznościach świadczących o demoralizacji ${ }^{23}$ nieletniego, w szczególności [...] używanie alkoholu lub innych środków w celu wprowadzenia się w stan odurzenia”, a w innym miejscu o „nieletnim, który popełnił czyn karalny i u którego stwierdzono nałogowe używanie alkoholu albo innych środków w celu wprowadzenia się w stan odurzenia" (art. 12). Z analizowanego aktu wyłaniają się zatem pojęcia autonomiczne - „używanie", „nałogowe używanie”, "inne środki" czy w końcu „stan odurzenia”. Biorąc pod uwagę, że ustawa o przeciwdziałaniu

z ich właściwego działania lub dla działań nieadekwatnych do potrzeby", K. Jędrzejko, W. Woszczyk, Lekomania - przyczyny i konsekwencje, „Problemy Narkomanii” 2007, nr 1, s. 11. Jeśli działanie leku jest nieadekwatne do potrzeby, wówczas osobę uzależnioną od jego działania można uznać za narkomana.

21 Ustawa z dnia 26 października 1982 r. o postępowaniu w sprawach nieletnich, tekst jednolity: Dz. U. z 2018 r. poz. 969.

22 Ustawa z dnia 23 kwietnia 1964 r. - Kodeks cywilny, tekst jednolity: Dz. U. z 2019 r. poz. 1145 (dalej: k.c.).

${ }^{23}$ Pojęcie demoralizacji nie pozwala się jednoznacznie zdefiniować. Jak zauważa T. Bojarski: ,jest więc niekiedy krytykowane jako - z jednej strony - wąskie, nieobejmujące wszystkich przejawów nieprzystosowania uzasadniającego uruchomienie odpowiednich działań, a z drugiej strony - jako nieprecyzyjne, mogące prowadzić do relatywizacji ocen, zawsze niepożądanej z punktu widzenia gwarancyjnej funkcji prawa", T. Bojarski, E. Kruk, E. Skrętowicz (red.), Ustawa o postępowaniu w sprawach nieletnich. Komentarz, wyd. 5, LEX 2018. 
narkomanii również posługuje się pojęciem „używanie”, tak i na gruncie ustawy o postępowaniu w sprawach nieletnich przyjąć można w drodze analogii, że przez pojęcie to należy rozumieć wprowadzenie do organizmu człowieka środka odurzającego, substancji psychotropowej, środka zastępczego, nowej substancji psychoaktywnej, niezależnie od drogi podania. „Nałóg” z kolei powinien być rozumiany jako nieodparte przyzwyczajenie do stosowania środka. Środkami innymi od alkoholu będą natomiast: środek odurzający, środek psychotropowy, środek zastępczy oraz inny środek toksyczny, zaś „,stan odurzenia” oznaczać powinien stan po spożyciu środka odurzającego wynikający z jego działania na ośrodkowy układ nerwowy.

Warto zaznaczyć, że na gruncie ustawy z 1982 r. nieletni, który wykazuje przejawy demoralizacji w związku z używaniem alkoholu i innych środków odurzających nie musi być narkomanem, albowiem posłużono się przesłanką jedynie używania środka, które nie prowadzi w każdym przypadku do powstania uzależnienia. Przywołane przepisy ustawy o postępowaniu $\mathrm{w}$ sprawach nieletnich znajdują jednak również inne, szersze zastosowanie. Artykuł 17 ustawy określa bowiem postępowanie wobec osoby uzależnionej, która nie ukończyła 18 lat. W tymże znaczeniu uznać należy osobę uzależnioną za "małoletniego narkomana”.

Dla ustalenia, czy dana osoba jest „dorosłym narkomanem”, czy też „nieletnim narkomanem”, wiążącym kryterium powinien być w każdym przypadku wiek określający możliwość ponoszenia odpowiedzialności za przestępstwo albo przestępstwo skarbowe. Kodeks karny wyznacza w tym przypadku dolną granicę 17 lat. Osoby, które nie osiągnęły tego wieku to "nieletni”.

Wątpliwości terminologiczne na gruncie prawa polskiego budzi także zaliczanie określonych środków do kategorii środków odurzających. Przesłanki uznania substancji za taki środek ulegały zmianie na przestrzeni lat.

Dostrzec należy w tym miejscu brak wspólnych semantycznych ram odniesienia do omawianego zagadnienia $w$ dziedzinach prawa i medycyny, a szerzej - na gruncie nauk społecznych i ścisłych. By udoskonalić sposób reagowania na sytuacje niepożądane, wydaje się, że wprowadzenie wspólnego aparatu pojęciowego będzie nieodzowne. Pars pro toto problemu rozbieżności interpretacyjnych może ukazać przykład pojęcia „narkomanii". Na gruncie nauk medycznych oznacza ono w najwęższym znaczeniu uzależnienie od jednej grupy środków - od opiatów 
i opioidów; w znaczeniu szerszym należy je rozpatrywać jako uzależnienie od środków psychoaktywnych ${ }^{24}$; gdy tymczasem uzależnienie od ogółu środków chemicznych powinno przybrać nazwę "toksykomanii", czyli stałego lub okresowego przyjmowania substancji wywołujących istotne zmiany $\mathrm{w}$ stanach psychiki, których dłuższe używanie prowadzi do zależności, chociażby tylko psychicznejej. Jednocześnie toksykomania uznawana jest za termin nadrzędny wobec innych - przez użycie tego terminu rozumieć trzeba narkomanię, lekomanię oraz skłonność do nadużywania innych używek szkodliwych dla zdrowia. Pojmuje się ją ponadto jako stan uzależnienia od trucizn, co uniemożliwia objęcie nim zjawiska farmakomanii. Stąd nawet przyjęcie najbardziej z pozoru ogólnego pojęcia "toksykomanii” w miejsce „narkomanii” jawi się jako nieuprawnione ${ }^{26}$.

Obowiązująca obecnie ustawa o przeciwdziałaniu narkomanii przez pojęcie „środek odurzający" rozumie każdą substancję pochodzenia naturalnego lub syntetycznego działającą na ośrodkowy układ nerwowy. Są one określone w wykazie środków odurzających stanowiącym załącznik nr 1 do ustawy (art. 4 pkt 27). Substancją psychotropową jest z kolei substancja określona w załączniku nr 2 do ustawy. Dwiema przesłankami,

${ }^{24}$ W tym znaczeniu: środki o działaniu odurzającym i uspokajającym, środki działające pobudzająco na ośrodkowy układ nerwowy, środki halucynogenne, zob. M. Jędrzejko, A. Kowalewska, Wptyw substancji psychoaktywnych na zdrowie $i$ zachowania człowieka, [w:] M. Jędrzejko (red.), Narkomania. Spojrzenie wielowymiarowe, Pułtusk 2008, s. 232-247.

${ }^{25}$ Inna klasyfikacja może polegać na przyjęciu, że „narkotyki dzielą się na trzy podstawowe grupy: depresantów (sedativa), a więc środków obniżających pobudliwość ośrodkowego układu nerwowego (do grupy tej należą np. opiaty i barbiturany), stymulantów (stimulantia), a więc środków pobudzających ośrodkowy układ nerwowy (do których należy przede wszystkim kokaina, a także środki z grupy amfetamin), czy wreszcie halucynogenów (psychedelica), to jest środków wywołujących przede wszystkim zmiany w sposobie postrzegania otoczenia (do których należą np. LSD, meskalina czy psylocybina), zob. J. Gierowski, K. Krajewski, K. Postulski [w:] L. Paprzycki (red.), System Prawa Karnego, t. 7, Warszawa 2015.

26 Na uwagę zasługuje tu odmienne rozumienie pojęcia „środek odurzający” na gruncie ustawy o przeciwdziałaniu narkomanii i ustawy Kodeks karny. Pierwsza z ustaw nie zalicza do tego pojęcia leków, druga ujmuje ten termin szerzej, obejmując nim nie tylko środki odurzające określone w ustawie o przeciwdziałaniu narkomanii, ale i wszelkiego rodzaju substancje pochodzenia naturalnego lub syntetycznego oddziałujące negatywnie na ośrodkowy układ nerwowy, powodując stan odurzenia, np. substancje psychotropowe lub zamienniki środków odurzających, w tym leki, zob. R. Stefański, Glosa do uchwaty SN $z$ dnia 27 lutego 2007 r., I KZP 36/06, „Prokuratura i Prawo” 2007, nr 8, s. 130-135. 
które powinny nastąpić łącznie, by zakwalifikować daną substancję do jednej z powyższych kategorii, jest zatem działanie na ośrodkowy układ nerwowy oraz zamieszczenie jej w załączniku do ustawy.

Omawiany akt prawny posługuje się także pojęciem „środka zastępczego", który stanowi produkt zawierający co najmniej jedną nową substancję psychoaktywną lub inną substancję o podobnym działaniu na ośrodkowy układ nerwowy, który może być użyty zamiast środka odurzającego lub substancji psychotropowej lub w takich samych celach jak środek odurzający lub substancja psychotropowa, których wytwarzanie i wprowadzanie do obrotu nie jest regulowane na podstawie przepisów odrębnych. Do środków zastępczych nie stosuje się przepisów o ogólnym bezpieczeństwie produktów.

Wspomnieć należy także o terminie ustawowym „nowa substancja psychoaktywna”. Stanowi ona substancję pochodzenia naturalnego lub syntetycznego w każdym stanie fizycznym, o działaniu na ośrodkowy układ nerwowy ${ }^{27}$, która została określona w przepisach wydanych na podstawie art. $44 \mathrm{~b}$ ust. $2^{28}$. Minister $\mathrm{w}$ drodze upoważnienia zawartego w podanym przepisie ustala "substancje lub ich grupy", co daje mu możliwość definiowania kontrolowanych substancji nie tylko w oparciu o listy indywidualnych substancji, ale również o ich grupy o określonej strukturze chemicznej. Takie podejście, wynikające z wejścia życie noweliza-

27 „Pod popularną nazwą «dopalacze» mieści się szeroka, bardzo zróżnicowana i stale rozrastająca się grupa związków, które można podzielić m.in. na: związki o charakterze amfetamino- i ekstazopochodnym (pochodne katynonu, piperazyny), syntetyczne związki halucynogenne (metoksetamina, związki z grupy 2C, NBOMe), związki o działaniu podobnym do marihuany (spice, K2), związki naśladujące działanie opioidów (AH-7921, MT-45), oraz pochodne benzodiazepiny, które nie znalazły zastosowania w medycynie (flubromazepam, etizolam, diklazepam)", E. Pieprzyca, E. Skowronek, C. Chowaniec, Problemy analityczne i interpretacyjne zwiąane z diagnostyka zatruć "dopalaczami", "Prokuratura i Prawo" 2018, nr 3, s. 116.

28 "Nowela do ustawy z 2005 r. o przeciwdziałaniu narkomanii (nowela z dnia 24 kwietnia 2015 r. Dz. U. z 2015 r., poz. 875) wprowadziła na listę aż 114 nowych substancji, które od dnia jej wejścia w życie, stały się substancjami kontrolowanymi. Ale nowela wprowadziła także zapis rewolucyjny z punktu widzenia polskich doświadczeń legislacyjnych: ustawodawca umożliwił definiowanie substancji zabronionych nie tylko w oparciu o indywidualne listy takich substancji, ale w oparciu o grupy substancji (tzw. definicje generyczne)", K. Tkaczyk-Rymanowska, Problem tzw. dopalaczy i nowych narkotyków w świetle zmian normatywnych do ustawy o przeciwdziałaniu narkomanii, „Prokuratura i Prawo” 2016, nr 9, s. 7, Legalis 2018. 
cji ustawy z 2015 r., umożliwiło skuteczniejszą walkę z tzw. dopalaczami, których coraz to nowe modyfikacje mogły być w poprzednim stanie prawnym wprowadzane do obrotu bez ograniczeń.

Zastosowana metoda legislacyjna pozwoliła objąć zakresem normowania ustawy również nowe środki, których nie zamieszczono w wykazach będących załącznikami do ustawy, z tym jednak zastrzeżeniem, że pojęcia "środków zastępczych" i "nowych substancji psychoaktywnych" pozostają irrelewantne na gruncie przepisów karnych zawartych w ustawie, ponieważ nie zostały wprowadzone do znamion żadnego z czynów zabronionych ${ }^{29}$.

Na podkreślenie zasługuje fakt, iż ustawa obejmuje swym zastosowaniem także kolejną kategorię substancji, tj. prekursorów. Są nimi substancje pochodzenia naturalnego lub syntetycznego, które mogą być przetworzone na środek odurzający lub substancję psychotropową albo mogą służyć do ich wytworzenia, określone w wykazie prekursorów stanowiącym załącznik nr 1 do ustawy.

Mając na względzie powyższe ustalenia służące wyjaśnieniu pojęć dotyczących przeciwdziałaniu narkomanii, nie można nie zauważyć, że nie są one ostre. Przyjęto różne metody definiowania, posługując się kryteriami przedmiotowymi jak i funkcjonalnymi, co wynika ze złożoności problemu i trudności w ustaleniu jednolitych kryteriów podziału. Normowane zjawiska społeczne okazują się nader dynamicznymi, by prawo odpowiadało na nie w sposób jednowymiarowy i z góry zaplanowany. Za właściwą należy jednocześnie uznać metodę zaliczania do katalogu „nowych substancji psychoaktywnych”, która łączy postulat określoności prawa z możnością zachowania przez prawodawcę cienia semantycznego definiowanych pojęć.

Dodać należy, że narkomania jest zagadnieniem stanowiącym pole badań wielu dziedzin, jak choćby psychologia, psychiatria czy pedagogika. Stąd rozbieżności pojęciowe w jej rozumieniu są nieuniknione. Nader

29 „Art. 52 ust. 1 ustawy z dnia 29 lipca 2005 r. o przeciwdziałaniu narkomanii (Dz. U. z 2005 r., Nr 179, poz. 1485 ze zm.) nie przewiduje przestępstwa polegającego na wprowadzeniu środków zastępczych do obrotu, obejmując ten czyn jedynie odpowiedzialnością administracyjną - kara pieniężna, której może podlegać osoba prawna, określaną w decyzji przez organ administracji, chyba, że działania osób zajmujących się tym procederem wywołają następstwa opisane w dyspozycji przepisu prawa karnego", wyrok Naczelnego Sądu Administracyjnego z dnia 8 lipca 2015 r., II OSK 2965/13, Legalis 2018 . 
trudnym wydaje się $\mathrm{w}$ związku z tym wyeliminowanie $\mathrm{w}$ dyskursie interdyscyplinarnym, pożądanym z punktu widzenia ustawodawcy, pojęć, którym towarzyszą niejasności ${ }^{30}$.

Dyskusja nad poruszonymi zagadnieniami uwzględniać musi jednocześnie wiążące Polskę normy prawa międzynarodowego. Zgodnie $\mathrm{z}$ art. 33 Konwencji o prawach dziecka ${ }^{31}$ :

Państwa-Strony będą podejmowały wszelkie odpowiednie kroki, w tym środki ustawodawcze, administracyjne, socjalne oraz środki $\mathrm{w}$ dziedzinie oświaty, w celu zapewnienia ochrony dzieci przed nielegalnym używaniem środków narkotycznych i substancji psychotropowych, zgodnie z ich zdefiniowaniem $w$ odpowiednich umowach międzynarodowych, oraz $w$ celu zapobiegania wykorzystywaniu dzieci do nielegalnej produkcji tego typu substancji i handlu nimi.

Krajowy porządek prawny powinien więc brać pod uwagę dorobek prawnomiędzynarodowy dotyczący omawianego zagadnienia. Mowa tu o konwencjach ratyfikowanych przez państwa zrzeszone w Organizacji Narodów Zjednoczonych, o podporządkowanym im Działaniu 96/750/ WSiSW z dnia 17 grudnia 1996 r., przyjętym przez Radę na podstawie art. K.3 Traktatu o Unii Europejskiej dotyczącym zbliżenia ustawodawstwa i praktyk Państw Członkowskich Unii Europejskiej w zakresie walki z narkomanią oraz zapobiegania i zwalczania nielegalnego handlu narkotykami, a także o decyzjach przyjmowanych przez Radę na podstawie Wspólnego Działania ${ }^{32}$.

\section{Problem nikotynizmu wśród małoletnich}

Aktem prawa ustalającym zasady obrotu wyrobami tytoniowymi jest ustawa z dnia 9 listopada 1995 r. o ochronie zdrowia przed następstwami

30 Szerzej o ujęciu medycznym, socjologicznym, psychologicznym i prawnym, zob. K. Łucarz, A. Muszyńska, Ustawa o przeciwdziałaniu narkomanii. Komentarz, Warszawa 2008, LEX 2018.

31 Konwencja o prawach dziecka, przyjęta przez Zgromadzenie Ogólne Narodów Zjednoczonych dnia 20 listopada 1989 r., Dz. U. z 1991 r. Nr 120, poz. 526 z późn. zm.

32 Zestawienie wszystkich aktów: https:// bip.ms.gov.pl/pl/ministerstwo/wspolpraca-miedzynarodowa/prawo-unii-europejskiej/narkotyki/ [dostęp: 31.05 .2018 r.]. 
używania tytoniu i wyrobów tytoniowych ${ }^{33}$. Wśród jej przepisów wyróżnić można te, które dotyczą małoletnich. Zgodnie z art. 6 ustawy: „Zabrania się udostępniania wyrobów tytoniowych, papierosów elektronicznych $^{34}$ lub pojemników zapasowych ${ }^{35}$ osobom do lat $18^{\prime \prime 36}$. W punkcie detalicznym umieszcza się widoczną i czytelną informację o treści: "Zakaz sprzedaży wyrobów tytoniowych, papierosów elektronicznych lub pojemników zapasowych osobom do lat 18 (art. 6 ust. 1 ustawy z dnia 9 listopada 1995 r. o ochronie zdrowia przed następstwami używania tytoniu i wyrobów tytoniowych)".

W ust. 2 omawianego przepisu zamieszczono wyczerpujący katalog jednostek, na terenie których zakazana jest całkowicie sprzedaż wyrobów tytoniowych. Tymi jednostkami są: podmioty wykonujące działalność leczniczą, szkoły ${ }^{37}$, placówki oświatowo-wychowawcze oraz obiekty sportowo-rekreacyjne.

Ustawa nakłada na organy administracji rządowej i samorządu terytorialnego obowiązek podejmowania działań zmierzających do ochrony zdrowia przed następstwami używania tytoniu, a także uprawnienie do wspierania w tym zakresie działalności medycznych samorządów zawodowych, organizacji społecznych, fundacji, instytucji i zakładów pracy, a także współdziałania z kościołami i innymi związkami wyznaniowymi (art. 1). Przywołana norma programowa nie traktuje jednak odrębnie następstw używania tytoniu w sytuacji małoletnich, z czego wynika, że ustawodawca uznaje nikotynizm za problem o wymiarze powszechnym.

33 Ustawa z dnia 9 listopada 1995 r. o ochronie zdrowia przed następstwami używania tytoniu i wyrobów tytoniowych, tekst jednolity: Dz. U. z 2018 r. poz. 1446 z późn. zm.

34 Wyrób, który może być wykorzystywany do spożycia pary zawierającej nikotynę za pomocą ustnika, lub wszystkie elementy tego wyrobu, w tym kartridże, zbiorniki i urządzenia bez kartridża lub zbiornika; papierosy elektroniczne mogą być jednorazowego użytku albo wielokrotnego napełniania za pomocą pojemnika zapasowego lub zbiornika lub do wielokrotnego ładowania za pomocą kartridżów jednorazowych (art. 2 pkt 20).

35 Naczynie z płynem zawierającym nikotynę, który można wykorzystać do ponownego napełnienia papierosa elektronicznego (art. 2 pkt 18).

36 Przyjąć należy, że zakaz obowiązuje bez względu, czy do sprzedaży dochodzi w stacjonarnym punkcie sprzedaży, czy też w sklepie internetowym.

37 „Określenie szkoła, użyte w art. 6 ust. 2 ustawy o ochronie zdrowia przed następstwami używania tytoniu i wyrobów tytoniowych, bez zawężających je przymiotników, dotyczy wszystkich rodzajów szkół, jakie funkcjonują w szeroko rozumianym systemie kształcenia, w tym także szkół wyższych, o których mowa w ustawie o szkolnictwie wyższym", wyrok Naczelnego Sądu Administracyjnego z dnia 7 października 2003 r., I SA 90/02, Legalis 2018. 
Takie podejście zasługuje na krytykę. Już choćby powszechna społeczna opinia skłania do piętnowania nikotynizmu wśród małoletnich i podjęcia szczególnych środków przeciwdziałania mu.

Leczenie uzależnienia od używania tytoniu jest finansowane na zasadach określonych w przepisach o świadczeniach opieki zdrowotnej finansowanych ze środków publicznych ${ }^{38}$.

Analizowana ustawa podlegała $\mathrm{w}$ minionych latach istotnym zmianom związanym m.in. z obowiązywaniem aktów prawa Unii Europejskiej. I tak nowelizacja z $2010 \mathrm{r} \cdot{ }^{39}$ miała na celu rozszerzenie obszarów objętych zakazem palenia tytoniu na większość miejsc publicznych oraz ujednolicenie sankcji za ich nieprzestrzeganie, a także dotyczyła zakazu reklamy wyrobów tytoniowych. Rozszerzyła nadto zakaz palenia na wszystkie obiekty użytku publicznego, miejsca pracy, środki transportu publicznego i związane z nimi obiekty oraz na obiekty sportowe i rekreacyjne. Uregulowała nadto kwestię palenia w bezpośrednim sąsiedztwie wejść i wyjść z miejsc publicznych. Wprowadziła również pewne ograniczenia palenia papierosów w prywatnych środkach transportu, zakaz palenia w obecności dzieci oraz zakaz w związku z wykonywaniem zarobkowym przewozu osób.

Kluczowa zmiana w przepisach ustawy antytytoniowej nastąpiła jednak w $2016 r r^{40}$ i związana była z koniecznością wdrożenia do systemu prawa krajowego dyrektywy Parlamentu Europejskiego i Rady 2014/40/ UE z dnia 3 kwietnia 2014 r. w sprawie zbliżenia przepisów ustawowych, wykonawczych i administracyjnych państw członkowskich w sprawie produkcji, prezentowania i sprzedaży wyrobów tytoniowych i powiązanych wyrobów oraz uchylającej dyrektywę 2001/37/WE ${ }^{41}$. Ustawa wprowadziła regulacje związane m.in. z oznaczeniem produktów tytoniowych

38 Regulacje dotyczące finansowania świadczeń opieki zdrowotnej, w tym leczenia od uzależnienia od używania tytoniu, zawierają przepisy działu II ustawy o świadczeniach opieki zdrowotnej finansowanych ze środków publicznych.

39 Ustawa z dnia 8 kwietnia 2010 r. o zmianie ustawy o ochronie zdrowia przed następstwami używania tytoniu i wyrobów tytoniowych oraz ustawę o Państwowej Inspekcji Sanitarnej, Dz. U. z 2010 r. Nr 81, poz. 529.

40 Ustawa z dnia 22 lipca 2016 r. o zmianie ustawy o ochronie zdrowia przed następstwami używania tytoniu i wyrobów tytoniowych, Dz. U. z 2016 r. poz. 1331.

41 Dyrektywa Parlamentu Europejskiego i Rady 2014/40/UE z dnia 3 kwietnia 2014 r. w sprawie zbliżenia przepisów ustawowych, wykonawczych i administracyjnych państw członkowskich w sprawie produkcji, prezentowania i sprzedaży wyrobów tytoniowych i powiązanych wyrobów oraz uchylająca dyrektywę 2001/37/WE, Dz. Urz. UE L 127/1 z 29.04.2014. 
oraz uporządkowała kwestie definicyjne związane z pojawieniem się nowych rozwiązań technologicznych $\mathrm{w}$ zakresie używania nikotyny (tzw. e-papierosy $)^{42}$. Przepis przejściowy art. 3 ustawy nowelizującej stanowi o stosowaniu od dnia 20 maja 2020 r. zakazu dotyczącego wyrobów tytoniowych o charakterystycznym aromacie zawierających dodatki mentolowe lub środki aromatyzujące o aromacie mentolowym, które nie powodują zwiększenia znacznie lub w wymiernym stopniu toksycznych lub uzależniających skutków wyrobów tytoniowych, lub ich właściwości CMR na etapie spożycia, stosownie do postanowień art. 7 ust. 14 dyrektywy.

W motywach dyrektywy zawarto spostrzeżenie, że wyroby tytoniowe nie są zwykłymi towarami, a wobec szczególnie szkodliwego wpływu tytoniu na zdrowie ludzkie należy nadać priorytet ochronie zdrowia, w szczególności ograniczeniu palenia wśród młodych ludzi. W tym kontekście z entuzjazmem przyjąć należy wykorzystanie narzędzi zmniejszających atrakcyjność wyrobów tytoniowych, na które składają się ograniczenia w reklamie ${ }^{43}$, oznakowaniu, a także wyeliminowanie ze sprzedaży środków aromatyzowanych, których właściwości uzależniające są silniejsze. Korzystnym dla zwalczania nikotynizmu wśród młodzieży jest ponad to zakaz sponsorowania przez firmę tytoniową, w tym producenta lub importera wyrobów tytoniowych oraz producenta lub importera powiązanych wyrobów, działalności sportowej, kulturalnej, oświatowej, zdrowotnej i społeczno-politycznej.

Artykuł 13 przywoływanej ustawy statuuje sankcję za udostępnienie małoletniemu wyrobu tytoniowego, papierosa elektronicznego lub pojemnika zapasowego. Polega ona na podleganiu karze grzywny do 2000 złotych wymierzanej w postępowaniu w sprawach o wykroczenia. Czyn ten ma charakter indywidualny, a więc może się go dopuścić jedynie właściciel bądź pracownik punktu sprzedaży.

Dokonując oceny omawianych przepisów, nie sposób nie zauważyć, że problemowi nikotynizmu wśród młodzieży ustawodawca nie poświęca tyle samo uwagi co zagadnieniom związanym z narkomanią. Wydaje się to słuszne z punktu widzenia różnej rangi zagrożenia, jaką niosą ze oba odnośne zjawiska.

42 Do chwili wejścia w życie dyrektywy implementującej elektroniczne papierosy mogły być bez ograniczeń nabywane przez małoletnich.

43 Zastosowano tu rozwiązanie podobne do przyjętego w ustawie o wychowaniu w trzeźwości i przeciwdziałaniu alkoholizmowi. 


\section{Bezpieczeństwo dzieci w Internecie}

Poruszanie się małoletnich $\mathrm{w}$ przestrzeni Internetu obarczone jest wieloma niebezpieczeństwami. Są one związane z narażeniem na wyświetlanie treści zabronionych, $\mathrm{w}$ tym propagowaniem agresji, prezentowaniem pornografii i wykorzystywaniem $\mathrm{w}$ popełnianiu przestępstw na tle seksualnym. Osoby małoletnie niewątpliwe cechuje łatwowierność, stąd duże ryzyko przekazywania przez nie danych osobowych własnych oraz osób najbliższych podmiotom nieuprawnionym. W tym kontekście wypada pozytywnie ocenić niektóre regulacje zawarte w Rozporządzeniu Parlamentu Europejskiego i Rady (UE) 2016/679 z dnia 27 kwietnia 2016 r. w sprawie ochrony osób fizycznych w związku z przetwarzaniem danych osobowych i w sprawie swobodnego przepływu takich danych oraz uchylenia dyrektywy 95/46/WE ${ }^{44}$. Dotychczas obowiązujące przepisy wynikające z ustawy z dnia 29 sierpnia 1997 r. o ochronie danych osobowych ${ }^{45}$ nie zawierały postanowień szczególnych dotyczących małoletnich.

Jak stanowi jeden z przywołanych motywów w pkt 38 rozporządzenia:

Szczególnej ochrony danych osobowych wymagają dzieci, gdyż mogą one być mniej świadome ryzyka, konsekwencji, zabezpieczeń i praw przysługujących im w związku z przetwarzaniem danych osobowych. Taka szczególna ochrona powinna mieć zastosowanie przede wszystkim do wykorzystywania danych osobowych dzieci do celów marketingowych lub do tworzenia profili osobowych lub profili użytkownika oraz do zbierania danych osobowych dotyczących dzieci, gdy korzystają one z usług skierowanych bezpośrednio do nich $^{46}$. Zgoda osoby sprawującej władzę rodzicielską lub opiekę nie powinna być konieczna w przypadku usług profilaktycznych lub doradczych oferowanych bezpośrednio dziecku.

44 Rozporządzenie Parlamentu Europejskiego i Rady (UE) 2016/679 z dnia 27 kwietnia 2016 r. w sprawie ochrony osób fizycznych w związku z przetwarzaniem danych osobowych i w sprawie swobodnego przepływu takich danych oraz uchylenia dyrektywy 95/46/WE (ogólne rozporządzenie o ochronie danych), Dz. Urz. UE L 119/1 z 4.05.2016.

45 Ustawa z dnia 29 sierpnia 1997 r. o ochronie danych osobowych, tekst jednolity: Dz. U. z 2016 r. poz. 922 [uchylona z dniem 6 lutego 2019 r.].

46 Wątpliwość budzić może, czy chodzi jedynie o usługi typowo przeznaczone dla dzieci np. profile na portalach oferujących udział w grach, czy też o wszelkie usługi, których adresatem może być dziecko. Potrzeba ochrony praw małoletnich przemawia z przyjęciem drugiej z proponowanych interpretacji. 
Z analizy pkt 71 wskazanego wstępu rozporządzenia wynika z kolei, że dziecko nie może być poddane profilowaniu, które polega na dowolnym zautomatyzowanym przetwarzaniu danych osobowych pozwalającym ocenić czynniki osobowe osoby fizycznej, a w szczególności analizować lub prognozować aspekty dotyczące efektów pracy, sytuacji ekonomicznej, zdrowia, osobistych preferencji lub zainteresowań, wiarygodności lub zachowania, lokalizacji lub przemieszczania się osoby, której dane dotyczą - o ile wywołuje skutki prawne względem tej osoby lub w podobny sposób znacząco na nią wpływa.

Z części normatywnej rozporządzenia można wywieść z kolei, że w przypadku usług społeczeństwa informacyjnego ${ }^{47}$ oferowanych bezpośrednio dziecku ${ }^{48}$, zgodne $\mathrm{z}$ prawem jest przetwarzanie danych osobowych dziecka, które ukończyło 16 lat ${ }^{49}$. Jeżeli dziecko nie ukończyło 16 lat, takie przetwarzanie jest zgodne $\mathrm{z}$ prawem wyłącznie w przypadkach, gdy zgodę wyraziła lub zaaprobowała ${ }^{50}$ ją osoba sprawująca władzę rodzicielską lub opiekę nad dzieckiem oraz wyłącznie w zakresie wyrażonej zgody. Państwa członkowskie mogą przewidzieć w swoim prawie niższą granicę wiekową, która musi wynosić co najmniej 13 lat ${ }^{51}$ (art. 8 ust. 1 rozporządzenia).

47 Należy przez nie rozumieć dostęp do różnego typu treści i funkcjonalności przez Internet - strony www, aplikacje itp., zob. M. Gawroński (red.), RODO. Przewodnik ze wzorami, Warszawa 2018, s. 87.

48 Chodzi o każdą usługę, normalnie świadczoną za wynagrodzeniem, na odległość, drogę elektroniczną i na indywidualne żądanie odbiorcy usług, z wyjątkiem usług inwestycyjnych, usług ubezpieczenia i reasekuracji, usług bankowych, operacji dotyczących funduszy emerytalnych oraz usługi związanej z obrotem transakcjami terminowymi i opcjami - art. 2 RODO odsyła do definicji zawartej w art. 1 ust. 1 lit. b dyrektywy Parlamentu Europejskiego i Rady (UE) 2015/1535. Usługa świadczona drogą elektroniczną nie musi być zgodnie z poglądami doktryny odpłatna, a celem przepisu nie jest ochrona portfeli rodziców, ale prywatności dzieci. Stąd odpłatność usług jest pomijana, zob. D. Lubasz [w:] E. Bielak-Jomaa, D. Lubasz (red.), RODO. Ogólne rozporządzenie o ochronie danych. Komentarz, Warszawa 2017, s. 431.

49 Wszelkie informacje i komunikaty - gdy przetwarzanie dotyczy dziecka - powinny być sformułowane tak jasnym i prostym językiem, by dziecko mogło je bez trudu zrozumieć.

50 Przekładając cytowaną normę na grunt prawa polskiego, należy opowiedzieć się za interpretacją polegającą na przyjęciu, że w omawianej sytuacji potrzebne będą 2 odrębne oświadczenia małoletniego i jego rodzica potwierdzającego dokonanie czynności prawnej na podstawie art. 17 k.c.

51 Osoby, który nie ukończyły 13 lat, jako nieposiadające zdolności do czynności prawnych, nie mogą złożyć skutecznego oświadczenia woli poza drobnymi, bieżącymi 
Kluczowym dla rozstrzygnięcia o możliwości przełożenia powyższej regulacji na grunt praktyki życia codziennego jest analiza art. 8 ust. 2 rozporządzenia, a stanowiącego: „W takich przypadkach administrator, uwzględniając dostępną technologię, podejmuje rozsądne starania, by zweryfikować, czy osoba sprawująca władzę rodzicielską lub opiekę nad dzieckiem wyraziła zgodę lub ją zaaprobowała".

Można mieć obawy, że pojęcie "dostępnej technologii” będzie interpretowane przez administratorów danych w sposób niekorzystny dla ochrony praw małoletnich. W praktyce trudno wyobrazić sobie skuteczną weryfikację zgody opiekuna małoletniego na przetwarzanie jego danych osobowych w sposób inny aniżeli w formie bezpośredniego kontaktu z administratorem. Takie założenie jawi się jednak jako niemożliwe w przypadku świadczenia usług społeczeństwa informacyjnego przez podmioty o zasięgu globalnym, jak platformy Google, Facebook, Instagram itp.

Autorzy P. Litwiński, P. Barta i M. Kawecki, proponują jako rozwiązanie posługiwanie się w celu uzyskania zgody adresem e-mail bądź numerem telefonu rodzica. Co prawda - jak podają - „nie daje ono pełnej gwarancji skutecznej identyfikacji tożsamości, ale bez wątpienia wzmacnia wiarygodność pozyskiwanych danych. Mechanizm weryfikacji tożsamości rodzica z wykorzystaniem adresu poczty elektronicznej wprowadzony został również do tzw. COPPA, a więc amerykańskiej ustawy o ochronie prywatności dzieci w sieci, która weszła w życie 1.04.2001 r." ${ }^{52}$

Ochrona bezpieczeństwa dzieci w przestrzeni Internetu na gruncie porządku prawa krajowego ograniczona została do zwalczania cyberprzestępczości seksualnej. Wśród mających zastosowanie przepisów Kodeksu karnego ${ }^{53}$ należy wymienić odnoszące się do:

1) przestępstw związanych z prezentowaniem, rozpowszechnianiem, produkowaniem, uzyskiwaniem lub posiadaniem treści pornograficznych za pośrednictwem Internetu - art. 202,

2) przestępstwa uwodzenia dziecka za pomocą systemu teleinformatycznego (tzw. grooming) - art. 200a $§ 1$ i 2,

sytuacjami życia codziennego. Zgodę w takim przypadku wyrazić może więc jedynie opiekun ustawowy.

52 P. Barta, M. Kawecki, Rozporządzenie UE w sprawie ochrony osób fizycznych w związku $z$ przetwarzaniem danych osobowych $i$ swobodnym przeptywem takich danych. Komentarz, B. Litwiński (red.), Warszawa 2018, s. 326.

53 Ustawa z dnia 6 czerwca 1997 r. - Kodeks karny, tekst jednolity: Dz. U. z 2018 r. poz. 1600 z późn. zm. 
3) przestępstwa propagowania lub pochwalania zachowań o charakterze pedofilskim - art. 200b.

Nadmienić wypada, że problem bezpieczeństwa małoletnich w Internecie znalazł odzwierciedlenie w szczątkowej regulacji ustawy z dnia 14 grudnia 2016 r. - Prawo oświatowe ${ }^{54}$. Zgodnie z art. 27 ustawy: „Szkoły i placówki zapewniające uczniom dostęp do Internetu są obowiązane podejmować działania zabezpieczające uczniów przed dostępem do treści, które mogą stanowić zagrożenie dla ich prawidłowego rozwoju, w szczególności zainstalować i aktualizować oprogramowanie zabezpieczające".

Do potencjalnych zagrożeń należą m.in. działanie złośliwych użytkowników z wnętrza sieci, możliwość ataku ze strony sieci Internet (przypadkowego lub intencjonalnego), dostęp do nieodpowiednich treści (narkotyki, przemoc, pornografia, hazard) czy naruszanie praw autorskich ${ }^{55}$. Jak zauważa M. Pilch:

Szkoła i placówka mają znaczny zakres swobody w realizacji celu zakładanego przez ustawodawcę $w$ art. 27. Ustawodawca używa bardzo ogólnego sformułowania: „podejmować działania zabezpieczające uczniów przed dostępem do treści [...]”. Nakaz, aby „w szczególności zainstalować i aktualizować oprogramowanie zabezpieczające", z uwzględnieniem sposobu rozumienia podobnych sformułowań na tle innych ustaw, można interpretować jako tylko przykładowe wskazanie, jakie działania powinny zostać podjęte. Natomiast o doborze konkretnych środków i form realizacji dyspozycji art. 27 decyduje autonomicznie dyrektor szkoły, na którym spoczywa wspomniany w art. 68 ust. 1 pkt 3 obowiązek sprawowania opieki nad uczniami oraz stwarzania im warunków harmonijnego rozwoju ${ }^{56}$.

Poza wskazaną wyżej regulacją nie można również pomijać obowiązków osób zatrudnionych w szkołach, które wynikają z przepisów o charakterze bardziej ogólnym. Każdy dyrektor ma obowiązek dbania o bezpieczeństwo uczniów na terenie szkoły, a bezpieczeństwo dostępu do treści internetowych mieści się $\mathrm{w}$ tym zakresie. Zgodnie z art. 5 ustawy każdy nauczyciel w swoich działaniach dydaktycznych, wychowawczych

54 Ustawa z dnia 14 grudnia 2016 r. - Prawo oświatowe, tekst jednolity: Dz. U. z 2019 r. poz. 1148 z późn. zm.

55 Zob. M. Pyter [w:] A. Balicki, M. Pyter (red.), Prawo oświatowe. Komentarz, Warszawa 2017, s. 85.

56 M. Pilich, Komentarz do ustawy - Prawo oświatowe, [w:] M. Pilich (red.), Prawo oświatowe oraz przepisy wprowadzajace. Komentarz, Warszawa 2017, LEX 2018. 
i opiekuńczych ma obowiązek kierowania się m.in. dobrem uczniów, troską o ich zdrowie (w tym także zdrowie psychiczne). Ponadto, zgodnie z art. 6 ustawy z dnia 26 stycznia 1982 r. - Karta Nauczyciela ${ }^{57}$, nauczyciel obowiązany jest rzetelnie realizować zadania związane z powierzonym mu stanowiskiem oraz podstawowymi funkcjami szkoły: dydaktyczną, wychowawczą i opiekunczą.

Biorąc powyższe pod uwagę, trzeba jednocześnie zaznaczyć, że zastany system prawa przewiduje zakaz cenzury prewencyjnej. Stosowanie ograniczeń w dostępie do informacji może więc w konkretnych przypadkach skutkować naruszeniem Konstytucji $\mathrm{RP}^{58}$, a także międzynarodowych aktów dotyczących praw człowieka ${ }^{59}$.

Wobec braku systemowej reakcji ustawodawcy na problematykę podatności małoletnich w Internecie na treści mogące prowadzić do uzależnienia bądź sprzyjające uzależnieniu ${ }^{60}$ słusznym postulatem wydaje się uświadamianie opiekunów ustawowych małoletnich o możliwości kształtowania stosunków prawnych w ten sposób, by umowy zawierane przez nich $\mathrm{z}$ dostawcami Internetu zawierały postanowienia o uprawnieniach związanych z kontrolowaniem treści, czy też przewidywały wyłączenie niektórych treści z dostępu ${ }^{61}$.

Abstrahując od zagrożeń związanych z dostępem małoletnich do Internetu, osobno należy potraktować problem e-uzależnienia, czyli patologicznego przywiązania do aktywności podejmowanej w świecie komunikowania się na odległość, któremu towarzyszy częściowa bądź całkowita rezygnacja z działań wymagających aktywności fizycznej oraz

57 Ustawa z dnia 26 stycznia 1982 r. - Karta Nauczyciela, tekst jednolity: Dz. U. z 2018 r. poz. 967 z późn. zm.

58 Art. 54 Konstytucji RP: „1. Każdemu zapewnia się wolność wyrażania swoich poglądów oraz pozyskiwania i rozpowszechniania informacji. 2. Cenzura prewencyjna środków społecznego przekazu oraz koncesjonowanie prasy są zakazane".

59 Np. art. 10 Konwencji o ochronie praw człowieka i podstawowych wolności sporządzonej w Rzymie dnia 4 listopada 1950 r., zmienionej następnie Protokołami nr 3, 5 i 8 oraz uzupełnionej Protokołem nr 2, Dz. U. z 1993 r. Nr 61, poz. 284.

60 Uzależnienie od Internetu samo w sobie trzeba uznać za doniosły problem społeczny.

${ }_{61}$ W myśl art. 175 ust. 1 ustawy z dnia 16 lipca 2004 r. - Prawo telekomunikacyjne, tekst jednolity: Dz. U. z 2018 r. poz. 1954 z późn. zm.: „Dostawca publicznie dostępnych usług telekomunikacyjnych, a jeżeli jest to konieczne - także operator publicznej sieci telekomunikacyjnej, są obowiązani podjąć środki techniczne i organizacyjne w celu zapewnienia bezpieczeństwa i integralności sieci, usług oraz przekazu komunikatów w związku ze świadczonymi usługami". 
nawiązywania bezpośrednich kontaktów międzyludzkich. Krajowe Biuro do Spraw Przeciwdziałania Narkomanii z upoważnienia Ministra Zdrowia przygląda się temu problemowi, angażując środki finansowe Funduszu Rozwiązywania Problemów Hazardowych (FRPH) przeznaczonego na realizację zadań z zakresu przeciwdziałania uzależnieniom behawioralnym. W celu zidentyfikowania zjawiska e-uzależnień - oprócz działań finansowanych ze środków FRPH - Krajowe Biuro podejmowało również inne działania uwzględniające powyższą tematykę, w tym np. zrealizowało badanie pod nazwą "Młodzież 2013”, które obejmowało m.in. charakterystykę zjawiska korzystania z Internetu przez młodzież. Problem uzależnień behawioralnych został także uwzględniony w sposób zintegrowany w Narodowym Programie Zdrowia na lata 2016-2020.

\section{Uwarunkowania prawne w zakresie udzielania pomocy dzieciom uzależnionym}

Cywilnoprawna kwalifikacja małoletniości obejmuje osoby, które nie ukończyły 18 roku życia bądź też które zawarły przed upływem tej daty związek małżeński ${ }^{62}$. Prawo posługuje się w takim przypadku pojęciem osoby niepełnoletniej. Oznacza to nieposiadanie pełnej zdolności do czynności prawnych, którą nabywa się w zakresie ograniczonym w momencie ukończenia 13 roku życia. Odmienność statusu osoby niepełnoletniej odznacza się w szczególności na gruncie przepisów prawa rodzinnego i opiekuńczego. Ochrona interesów takiej osoby znajduje wyraz m.in. w obowiązku wszczęcia przez sąd opiekuńczy postępowania z urzędu, gdy ten poweźmie wiadomości o okolicznościach uzasadniających ingerencję, np. gdy dostrzeże niewłaściwe wykonywanie władzy rodzicielskiej. Zawiadomienie sądu o powyższych okolicznościach stanowi zgodnie z art. $572 \S 1$ k.p.c. obowiązek każdego, kto znalazł się w posiadaniu informacji o nich. Ten sam artykuł w § 2 precyzuje, że obowiązek wymieniony w § 1 ciąży

62 Z kolei osobą małoletnią w rozumieniu przepisów karnych (u.p.n.) jest osoba, która nie ukończyła 18 roku życia, bez względu na jej status matrymonialny. „Wynik wykładni dokonanej na podstawie dyrektywy języka ogólnego koresponduje bowiem z ustaleniami poczynionymi na gruncie funkcjonalnych dyrektyw wykładni i nie znajduje kontrargumentów w perspektywie systemowych reguł interpretacyjnych", T. Kozioł, "Małoletni" jako znamię przestępstw narkotykowych, „Przegląd Sądowy” 2017, nr 6, s. 97. 
przede wszystkim na urzędach stanu cywilnego, sądach, prokuratorach, notariuszach, komornikach, organach samorządu i administracji rządowej, organach policji, placówkach oświatowych, opiekunach społecznych oraz organizacjach i zakładach zajmujących się opieką nad dziećmi lub osobami psychicznie chorymi. Wyrażenie „przede wszystkim” sugeruje jednocześnie, że podany katalog podmiotów ma charakter otwarty. Warto na marginesie podkreślić, że norma zawarta w przywołanym przepisie nie przewiduje sankcji za niedopełnienie obowiązku, nie zakreśla terminu do dokonania zawiadomienia ${ }^{63}$, ani też nie ustala formy, w której powinno się ono odbyć.

Jak wynika z art. 6 omawianej wcześniej ustawy z dnia 26 października 1982 r. o postępowaniu w sprawach nieletnich, sąd rodzinny w sytuacji stwierdzenia okoliczności świadczących o demoralizacji nieletniego może zastosować wobec niego szereg środków o charakterze wychowawczo-poprawczym. W razie stwierdzenia u nieletniego upośledzenia umysłowego, choroby psychicznej lub innego zakłócenia czynności psychicznych bądź nałogowego używania alkoholu albo innych środków w celu wprowadzenia się w stan odurzenia, sąd rodzinny może orzec umieszczenie nieletniego $\mathrm{w}$ szpitalu psychiatrycznym lub innym odpowiednim zakładzie leczniczym (art. 12) ${ }^{64}$.

Ochrona zdrowia uzależnionych, jak i ochrona zdrowia publicznego, przesądziły o możliwości poddania przymusowemu leczeniu alkoholików na podstawie art. 26 ustawy o wychowywaniu w trzeźwości, a w myśl art. 30 ust. 1 ustawy o przeciwdziałaniu narkomanii - przymusowemu leczeniu małoletnich uzależnionych od narkotyków.

Leczenie odwykowe osób uzależnionych od alkoholu prowadzi się w zakładach leczniczych podmiotów wykonujących działalność leczniczą w rodzaju świadczenia stacjonarne i całodobowe oraz ambulatoryjne w rozumieniu przepisów o działalności leczniczej. Poddanie się leczeniu odwykowemu jest dobrowolne, jednakże u.ozw.alk. dopuściła wyjątki od tej zasady umożliwiające poddanie osoby uzależnionej od alkoholu obowiązkowi leczenia na podstawie orzeczenia sądu - to rozkład życia

63 Zob. J. Bodio [w:] A. Jakubecki (red.), Kodeks postępowania cywilnego. Komentarz aktualizowany. Tom I. Art. 1-729, LEX/el. 2018.

${ }^{64}$ Nie jest konieczną przesłanką popełnienie przez nieletniego czynu karalnego, o czym przesądził Sąd Najwyższy już w 1984 r., zob. uchwała Sądu Najwyższego z dnia 21 listopada 1984 r., III CZP 47/84, OSNC 1985/5-6/64. 
rodzinnego, demoralizacja małoletnich, uchylanie się od pracy oraz systematyczne zakłócania spokoju lub porządku publicznego ${ }^{65}$. Do zastosowania przymusowego leczenia odwykowego nie wystarczy samo stwierdzenie uzależnienia od alkoholu (przesłanka medyczna), lecz konieczne jest również wykazanie, że jest ono powodem negatywnych zjawisk (przesłanka społeczna), które muszą wystąpić, aby sąd mógł orzec o obowiązku poddania się osoby uzależnionej od alkoholu leczeniu odwykowemu ${ }^{66}$.

Oprócz wskazanego trybu, ustawa przewiduje również poddanie leczeniu odwykowemu osób przebywających w zakładach poprawczych lub schroniskach dla nieletnich. Uprawnionym organem do skierowania na takie leczenie jest administracja zakładu. Musi jednak uzyskać w przypadku małoletnich zgodę przedstawiciela ustawowego.

Jak zauważa R. Kubiak:

Omawiana regulacja (Ustawa o wychowaniu w trzeźwości) jest krytykowana w literaturze. Wskazuje się, że ustawodawca jest niekonsekwentny, gdyż dopuszcza przymusowe leczenie pełnoletnich osób uzależnionych od alkoholu, gdy w przypadku narkomanii dotyczy to tylko osób małoletnich. Ponadto podnosi się, że sformułowania użyte w przesłankach materialnych są nieostre, co powoduje, iż nie jest jasne, kiedy unormowanie to może być stosowane ${ }^{67}$.

W pozostałych wypadkach badanie lub udzielenie pacjentowi innego świadczenia zdrowotnego bez jego zgody jest dopuszczalne, jeżeli wymaga on niezwłocznej pomocy lekarskiej, a ze względu na stan zdrowia lub wiek nie może wyrazić zgody i nie ma możliwości porozumienia się z jego przedstawicielem ustawowym lub opiekunem faktycznym ${ }^{68}$.

Podobny środek stanowi przymusowe leczenie lub rehabilitacja wobec skazanych na karę pozbawienia wolności, u których stwierdzono uzależnienie od alkoholu albo środków odurzających lub psychotropowych (art. 117 k.k.w.) ${ }^{69}$.

65 Wydaje się, że w przypadku małoletnich zasadnym będzie orzekanie leczenia przymusowego jedynie na podstawie ostatniej z wymienionych przesłanek.

${ }_{66}$ Zob. postanowienie Sądu Okręgowego w Nowym Sączu z dnia 23 października 2013 r., III CA 642/12, LEX 2018.

67 R. Kubiak, Prawo medyczne, Warszawa 2017, s. 171.

68 Art. 33 ustawy z dnia 5 grudnia 1996 r. o zawodach lekarza i lekarza dentysty, tekst jednolity: Dz. U. z 2019 r. poz. 537 z późn. zm.

69 Ustawa z dnia 6 czerwca 1997 r. - Kodeks karny wykonawczy, tekst jednolity: Dz. U. z 2019 r. poz. 676 z późn. zm. (dalej: k.k.w.). 


\section{Zakończenie}

Ponoszenie odpowiedzialności karnej za przestępstwa i wykroczenia związane z uzależnieniami, a także za przestępstwa towarzyszące temu zjawisku, jak np. kradzieże czy rozboje podejmowane w celu uzyskania środków na zdobycie substancji uzależniających oraz akty przemocy pod wpływem tych substancji, częstokroć prowadzi do powstania u osoby, przeciwko której toczy się postępowanie, a przebywającej w placówce leczenia uzależnień, stanów lękowych, obaw czy poczucia bezradności, co niestety wzmagać może stan uzależnienia. Mechanizm ten potęguje się, gdy uzależnionego dotykają jednocześnie reperkusje o charakterze cywilnoprawnym, w tym rosnące zadłużenie, ciążące postępowania sądowe i egzekucyjne ${ }^{70}$, a także zobowiązania prawnorodzinne przy braku wsparcia najbliższego środowiska i instytucji państwowych.

Mając powyższe na uwadze, za wskazane należałoby uznać zmianę prawa w celu zapewnienia uzależnionemu, już na etapie leczenia stacjonarnego czy ambulatoryjnego, niezbędnej pomocy prawnej oraz wsparcia pracownika socjalnego. Równoległy proces leczenia i redukowania zobowiązań umożliwiłby choremu szybszą integrację społeczną, co harmonizowałoby ponadto $\mathrm{z}$ interesem publicznym oraz prawami osób trzecich.

Małoletni uzależnieni nie mogą być pozbawiani wsparcia osób najbliższych, zwłaszcza tych, na których ciąży względem małoletnich obowiązek alimentacyjny. Domaganie się wsparcia przez małoletniego nie będzie w sytuacji silnego uzależnienia uznawane za nadużycie prawa, nawet w sytuacji oddalenia emocjonalnego, nieokazywania wdzięczności, czy wręcz okazywania postaw wrogich lub negatywnie ocenianych przez prawo. Opiekunowie małoletnich muszą wziąć pod uwagę emocjonalny rozwój dziecka oraz fakt, że stan uzależnienia jest najczęściej skutkiem

70 Zauważyć trzeba na przykład, że małoletniemu wytwarzającemu lub wprowadzającemu do obrotu środek zastępczy lub nową substancję psychotropową zagraża dotkliwa sankcja w formie kary pieniężnej nakładanej na podstawie art. 52a ustawy o przeciwdziałaniu narkomanii w wysokości od 20.000 do 1.000 .000 złotych. Z punktu widzenia normy art. 52a u.p.n. obojętne jest zarówno to, czy dane udostępnienie środka zastępczego było pierwotnym, czy też kolejnym etapem wprowadzenia do obrotu, jak również to, jaką rolę spełniała osoba udostępniająca środek zastępczy, a więc, czy działała na własny rachunek, czy w ramach współsprawstwa, w tym w ramach łączącego ją stosunku prawnego z inną osobą (np. stosunku pracy, zlecenia), zob. wyrok Wojewódzkiego Sądu Administracyjnego w Bydgoszczy z dnia 21 lutego 2017 r., II SA/Bd/ 1005/16, LEX 2018. 
zaniechań w zakresie sprawowania pieczy nad podopiecznym. Świadczenie alimentacyjne nie musi jednak przybierać postaci pieniężnej. Orzecznictwo Sądu Najwyższego przyjmuje bowiem, że zaspokajanie usprawiedliwionych potrzeb osoby uprawnionej potrzebującej alimentacji może polegać na dostarczeniu mieszkania, opieki lekarskiej i domowej ${ }^{71}$. W sytuacji uzależnienia wskazanym jest zatem odstąpienie od dokonywania przysporzeń pieniężnych, które trudno opiekunowi kontrolować, na rzecz czynienia wyłącznie osobistych starań.

Reagowanie na zagrożenia uzależnieniami u małoletnich spoczywa na ich opiekunach ustawowych. Należy pamiętać równocześnie o roli sądu opiekuńczego oraz jednostek organizacyjnych wspierania rodziny i systemu pieczy zastępczej, która wynika wprost z art. 100 Kodeksu rodzinnego i opiekuńczego ${ }^{72}$. Sędzia, asesor sądowy oraz sąd rodzinny współpracują przy tym z organami, instytucjami i organizacjami społecznymi zajmującymi się na danym terenie problematyką rodziny, dzieci i młodzieży, sprawami oświaty i wychowania oraz zdrowia ${ }^{73}$.

Słowa kluczowe: uzależnienia, narkotyki, alkohol, nikotynizm, Internet, nieletni

\section{Bibliografia}

\section{Źródła prawa}

\section{Akty prawa międzynarodowego i polskiego}

Konwencja o Ochronie Praw Człowieka i Podstawowych Wolności sporządzona w Rzymie dnia 4 listopada 1950 r., zmieniona następnie Protokołami nr 3, 5 i 8 oraz uzupełniona Protokołem nr 2, Dz. U. z 1993 r. Nr 61, poz. 284.

Konwencja o prawach dziecka, przyjęta przez Zgromadzenie Ogólne Narodów Zjednoczonych dnia 20 listopada 1989 r., Dz. U. z 1991 r. Nr 120, poz. 526 z późn. zm.

Ustawa z dnia 25 lutego 1964 r. - Kodeks rodzinny i opiekuńczy, tekst jednolity: Dz. U. z 2017 r. poz. 682 z późn. zm.

71 Zob. wyrok Sądu Najwyższego z dnia 6 maja 1967 r., III CR 422/66, LEX 2018.

72 Ustawa z dnia 25 lutego 1964 r. - Kodeks rodzinny i opiekuńczy, tekst jednolity: Dz. U. z 2017 r. poz. 682 z późn. zm.

73 § 219 rozporządzenia Ministra Sprawiedliwości z dnia 23 grudnia 2015 r. Regulamin urzędowania sądów powszechnych, Dz. U. z 2015 r. poz. 2316. 
Ustawa z dnia 17 listopada 1964 r. Kodeks postępowania cywilnego, tekst jednolity: Dz. U. z 2019 r. poz. 1460.

Ustawa z dnia 23 kwietnia 1964 r. - Kodeks cywilny, tekst jednolity: Dz. U. z 2019 r. poz. 1145.

Ustawa z dnia 26 stycznia 1982 r. - Karta Nauczyciela, tekst jednolity: Dz. U. z 2018 r. poz. 967 z późn. zm.

Ustawa z dnia 26 października 1982 r. o postępowaniu w sprawach nieletnich, tekst jednolity: Dz. U. z 2018 r. poz. 969.

Ustawa z dnia 26 października 1982 r. o wychowaniu w trzeźwości i przeciwdziałaniu alkoholizmowi, tekst jednolity: Dz. U. z 2018 r. poz. 2137.

Ustawa z dnia 9 listopada 1995 r. o ochronie zdrowia przed następstwami używania tytoniu i wyrobów tytoniowych, tekst jednolity: Dz. U. z 2018 r. poz. 1446 z późn. zm.

Ustawa z dnia 5 grudnia 1996 r. o zawodach lekarza i lekarza dentysty, tekst jednolity: Dz. U. z 2019 r. poz. 537 z późn. zm.

Ustawa z dnia 6 czerwca 1997 r. - Kodeks karny, tekst jednolity: Dz. U. z 2018 r. poz. 1600 z późn. zm.

Ustawa z dnia 6 czerwca 1997 r. - Kodeks karny wykonawczy, tekst jednolity: Dz. U. z 2019 r. poz. 676 z późn. zm.

Ustawa z dnia 16 lipca 2004 r. - Prawo telekomunikacyjne, tekst jednolity: Dz. U. z 2018 r. poz. 1954 z późn. zm.

Ustawa z dnia 27 sierpnia 2004 r. o świadczeniach opieki zdrowotnej finansowanych ze środków publicznych, tekst jednolity: Dz. U. z 2019 r. poz. 1373 z późn. zm.

Ustawa z dnia 29 lipca 2005 r. o przeciwdziałaniu narkomanii, tekst jednolity: Dz. U. z 2019 r. poz. 852.

Ustawa z dnia 8 kwietnia 2010 r. o zmianie ustawy o ochronie zdrowia przed następstwami używania tytoniu i wyrobów tytoniowych oraz ustawy o Państwowej Inspekcji Sanitarnej, Dz. U. z 2010 r. Nr 81, poz. 529.

Ustawa z dnia 22 lipca 2016 r. o zmianie ustawy o ochronie zdrowia przed następstwami używania tytoniu i wyrobów tytoniowych, Dz. U. z 2016 r. poz. 1331.

Ustawa z dnia 14 grudnia 2016 r. - Prawo oświatowe, tekst jednolity: Dz. U. z 2019 r. poz. 1148 z późn. zm.

Dyrektywa Parlamentu Europejskiego i Rady 2014/40/UE z dnia 3 kwietnia 2014 r. w sprawie zbliżenia przepisów ustawowych, wykonawczych i administracyjnych państw członkowskich w sprawie produkcji, prezentowania i sprzedaży wyrobów tytoniowych i powiązanych wyrobów oraz uchylająca dyrektywę 2001/37/WE, Dz. Urz. UE L 127/1 z 29.04.2014.

Rozporządzenie Parlamentu Europejskiego i Rady (UE) 2016/679 z dnia 27 kwietnia 2016 r. w sprawie ochrony osób fizycznych w związku z przetwarzaniem danych osobowych i w sprawie swobodnego przepływu takich danych oraz 
uchylenia dyrektywy 95/46/WE (ogólne rozporządzenie o ochronie danych), Dz. Urz. UE L 119/1 z 4.05.2016.

Rozporządzenie Ministra Zdrowia z dnia 8 grudnia 2014 r. w sprawie izb wytrzeźwień i placówek wskazanych lub utworzonych przez jednostkę samorządu terytorialnego, Dz. U. z 2014 r. poz. 1850.

Rozporządzenie Ministra Sprawiedliwości z dnia 23 grudnia 2015 r. Regulamin urzędowania sądów powszechnych, Dz. U. z 2015 r. poz. 2316.

\section{Orzecznictwo}

Wyrok Sądu Najwyższego z dnia 6 maja 1967 r., III CR 422/66, LEX 2018.

Uchwała Sądu Najwyższego z dnia 21 listopada 1984 r., III CZP 47/84, OSNC 1985/5-6/64.

Wyrok Naczelnego Sądu Administracyjnego oz. w Katowicach z dnia 13 lipca 1994 r., SA/KA 30/94, Centralna Baza Orzeczeń Sądów Administracyjnych (CBOSA).

Wyrok Naczelnego Sądu Administracyjnego z dnia 7 października 2003 r., I SA 90/02, Legalis 2018.

Wyrok Naczelnego Sądu Administracyjnego z dnia 8 lipca 2015 r., II OSK 2965/13, Legalis 2018.

Wyrok Wojewódzkiego Sądu Administracyjnego w Lublinie z dnia 24 września 2013 r., III SA/Lu 335/13, CBOSA.

Wyrok Wojewódzkiego Sądu Administracyjnego w Bydgoszczy z dnia 21 lutego 2017 r., II SA/Bd/ 1005/16, LEX 2018.

Postanowienie Sądu Okręgowego w Nowym Sączu z dnia 23 października 2013 r., III CA 642/12, LEX 2018.

\section{Literatura}

Balicki A., M. Pyter (red.), Prawo oświatowe. Komentarz, Warszawa 2017.

Barta P., M. Kawecki, Rozporządzenie UE w sprawie ochrony osób fizycznych w związ$k u$ z przetwarzaniem danych osobowych i swobodnym przeptywem takich danych. Komentarz, B. Litwiński (red.), Warszawa 2018.

Bielak-Jomaa E. (red.), RODO. Ogólne rozporządzenie o ochronie danych. Komentarz, Warszawa 2017.

Bojarski T., E. Kruk, E. Skrętowicz (red.), Ustawa o postępowaniu w sprawach nieletnich. Komentarz, wyd. 5, LEX 2018.

Dercz M., Konstytucyjne prawo dziecka do szczególnej opieki zdrowotnej, Warszawa 2016.

Gaberle A., Patologia społeczna, Warszawa 1993.

Gawroński M. (red.), RODO. Przewodnik ze wzorami, Warszawa 2018.

Jakubecki A. (red.), Kodeks postępowania cywilnego. Komentarz aktualizowany. Tom I. Art. 1-729, LEX/el. 2018. 
Jędrzejko K., W. Woszczyk, Lekomania - przyczyny i konsekwencje, „Problemy Narkomanii" 2007, nr 1, s. 5-17.

Jędrzejko M. (red.), Narkomania. Spojrzenie wielowymiarowe, Pułtusk 2008.

Kozioł T., "Małoletni" jako znamię przestępstw narkotykowych, "Przegląd Sądowy” 2017, nr 6, s. 91-99.

Kubiak R., Prawo medyczne, Warszawa 2017.

Łucarz K., A. Muszyńska, Ustawa o przeciwdziałaniu narkomanii. Komentarz, Warszawa 2008.

Muszyńska A., Narkomani. Sprawcy czynów karalnych, Kraków 2004.

Paprzycki L. (red.), System Prawa Karnego, t. 7, Warszawa 2015.

Pieprzyca E., E. Skowronek, C. Chowaniec, Problemy analityczne i interpretacyjne zwiazane z diagnostyka zatruć „dopalaczami”, „Prokuratura i Prawo” 2018, nr 3, s. 116-124.

Pilich M. (red.), Prawo oświatowe oraz przepisy wprowadzające. Komentarz, LEX 2018. Sierosławski J., Używanie substancji psychoaktywnych przez młodzież w 2015 r., Europejski Program Badań Ankietowych w Szkołach na temat używania alkoholu i narkotyków, http:/ / www.cinn.gov.pl/portal?id=907006 [dostęp: 22.05 .2018 r.].

Skrzydło-Niżnik I., G. Zalas, Ustawa o wychowaniu w trzeźwości i przeciwdziałaniu alkoholizmowi. Komentarz, Kraków 2002.

Srogosz T., Ustawa o przeciwdziałaniu narkomanii. Komentarz, Warszawa 2008.

Stefański R., Glosa do uchwały SN z dnia 27 lutego 2007 r., I KZP 36/06, „Prokuratura i Prawo" 2007, nr 8, s. 130-135.

Tkaczyk-Rymanowska K., Problem tzw. dopalaczy i nowych narkotyków w świetle zmian normatywnych do ustawy o przeciwdziałaniu narkomanii, „Prokuratura i Prawo" 2016, nr 9, s. 131-145.

\section{CHILDREN'S ADDICTIONS - LEGAL ANALYSIS}

\section{Sum mary}

Children's addiction in the legal perspective is a multifaceted issue. The article refers to three types of addiction: alcoholism, drug addiction and nicotinism. Its authors analyze ranges of selected terms in public and private law, noting also the influence of international law on discussed legislation. Undertaken considerations have been supplemented by the context of children's movement in the Internet space. Essential guarantees associated with this are included, among others, in The General Data Protection Regulation (EU) 2016/679 (so called „GDPR”). The article also includes analysis of legal conditions for providing assistance to minors affected by addictions. The analytical part of the study is completed by de lege lata postulates.

Key words: addictions, drugs, alcohol, nicotine, Internet, minors 


\section{ПРАВОВЫЕ АСПЕКТЫ ДЕТСКОЙ ЗАВИСИМОСТИ}

\section{Резюме}

Проблема детской зависимости на основании закона является многогранной проблемой. В этой статье рассматриваются три типа зависимости: алкоголизм, наркомания и никотинизм. Авторы анализируют ряд отдельных понятий в публичном и частном праве, отмечая также появление существующих стандартов в международном правопорядке. Дополнением к соображениям является вложение обсуждаемой проблемы в контекст нахождение детей в интернет-пространстве. Гарантии, связанные с этим, включают, среди прочего Постановление Европейского парламента и Совета (ЕС) 2016/679 от 27 апреля 2016 года о защите физических лиц при обработке персональных данных. Публикация также включает правовые условия оказания помощи несовершеннолетним, пострадавшим от вредных привычек. Аналитическая часть исследования дополнена постулатами de lege lata.

Ключевые слова: наркомания, наркотики, алкоголь, никотинизм, интернет, несовершеннолетние 
